\title{
The Role of Peer Support, Superior Support, Training Self- Efficacy, Training Needs and Opportunity to Use on Readiness to Participate in Training Among Civil Servants in Nigeria.
}

Nnamdi Ogbodoakum, Ahmad Fauzi Mohd Ayub, Norhasni Zainal Abiddin

To Link this Article: http://dx.doi.org/10.6007/IJARBSS/v10-i12/8142 DOI:10.6007/IJARBSS/v10-i12/8142

Received: 29 October 2020, Revised: 21 November 2020, Accepted: 30 November 2020

Published Online: 24 December 2020

In-Text Citation: (Ogbodoakum et al., 2020)

To Cite this Article: Ogbodoakum, N., Ayub, A. F. M., \& Abiddin, N. Z. (2020). The Role of Peer Support, Superior Support, Training Self-Efficacy, Training Needs and Opportunity to Use on Readiness to Participate in Training Among Civil Servants in Nigeria. International Journal of Academic Research in Business and Social Sciences, 10(12), 868-887.

\section{Copyright: (c) 2020 The Author(s)}

Published by Human Resource Management Academic Research Society (www.hrmars.com) This article is published under the Creative Commons Attribution (CC BY 4.0) license. Anyone may reproduce, distribute, translate and create derivative works of this article (for both commercial and non-commercial purposes), subject to full attribution to the original publication and authors. The full terms of this license may be seen at: http://creativecommons.org/licences/by/4.0/legalcode

$$
\text { Vol. 10, No. 12, 2020, Pg. } 868 \text { - } 887
$$

Full Terms \& Conditions of access and use can be found at http://hrmars.com/index.php/pages/detail/publication-ethics 


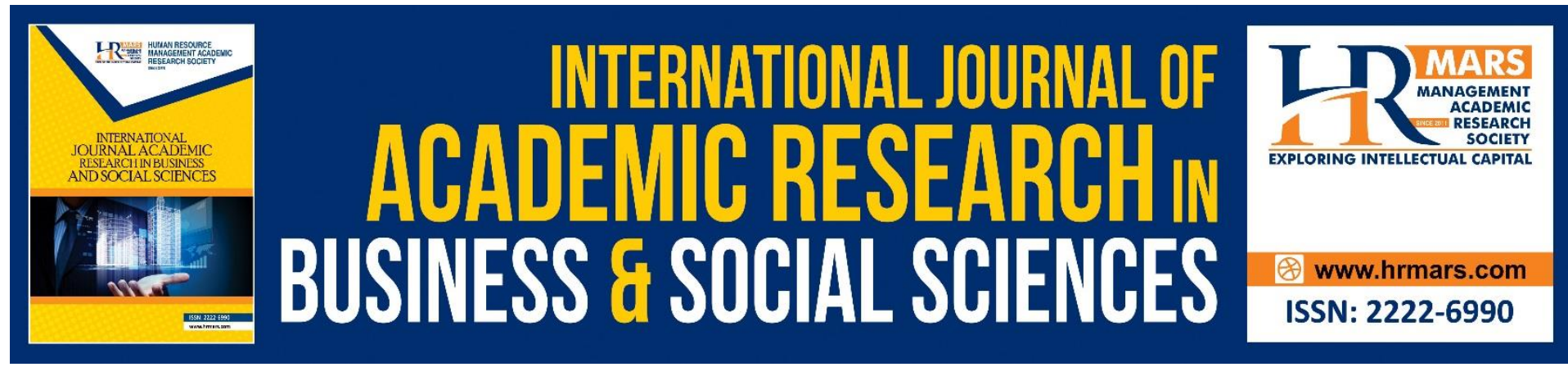

\title{
The Role of Peer Support, Superior Support, Training Self-Efficacy, Training Needs and Opportunity to Use on Readiness to Participate in Training Among Civil Servants in Nigeria.
}

\author{
Nnamdi Ogbodoakuma ${ }^{\mathrm{a}}$, Ahmad Fauzi Mohd Ayub ${ }^{\mathrm{b}}$, Norhasni \\ Zainal Abiddinc \\ ${ }^{a, b}$ Faculty of Educational Studies, Universiti Putra Malaysia, 'National Defence University of \\ Malaysia, Royal Malaysian Navy, Lumut, Perak, Malaysia. \\ Email: ogbodoakumnnamdi@gmail.com
}

\begin{abstract}
The purpose of the study is to examine the relationships between peer support, superior support, training self-efficacy, training needs and opportunity to use on readiness to participate in training. The descriptive-survey study, which was based on a sample of 255 civil servants from three organizations in Nigeria was analyzed with structural equation modeling. The findings show that peer support had direct and indirect significant relationships with readiness to participate. Opportunity to use partially mediated the effect of peer support on readiness to participate while superior support, training self-efficacy and training needs were fully mediated by opportunity to use. Finally, opportunity to use accounted for $40.5 \%$ of the variance while readiness to participate explained $58.6 \%$ of variance. The findings of the study would be primarily valuable to human resource development practitioners and policy makers in ensuring that employees have strong readiness to participate in training before such intervention is embarked on, especially in an environment, such as the civil service where motivation for personal development is low. Worthy of note was that superior support, training self-efficacy and training needs without opportunity to use the acquired knowledge, skills and abilities would not generate the expected readiness to participate especially in an environment where motivation for personal development is low.
\end{abstract}

Keywords: Readiness to Participate, Opportunity to Use, Peer Support, Superior Support, Training self-efficacy, Training Need.

\section{Introduction}

World Economic Forum (2018) report on future of jobs; argued that the fourth industrial revolution, demands sustained actions from policy makers, educators and organisational leaders to maximize emerging technologies, optimize job relevant skills and invest heavily on training and upskilling of workforce. The warning is suggestive that, even though substantial efforts have been recorded in the domain of work-related innovations, the increasing disruptive nature of many of the current work design cast doubt on the sustainability of 
present organizational ecosystems. While training has been acknowledged as essential tool to achieve range of organizational outcomes such as improved organizational performance and service delivery (Banerjee, Gupta \& Bates, 2016; Berkley \& Kaplan, 2019; Willyerd \& Mistick, 2106), very few organizations have realised the desired benefits of such investments. Despite overwhelming consensus that, employees hardly transfer the training knowledge and skills into the workplace (Gegenfurtner et al., 2009a, 2018; Grossman \& Salas, 2011; Massenberg, Spurk \& Kauffeld, 2015), scholars have focused on individual and contextual factors that predict training transfer (Kim, Park \& Kang, 2019; Machin \& Treloar, 2004; Park, Kang \& Kim, 2018), with little efforts on readiness status of employees before such training. Without establishing sufficient employees' readiness to participate; much desired training outcomes would be difficult, especially in a cultural inhibitive, rule based and hierarchical civil service. In the current study, this writer is arguing that lack of sufficient readiness to participate in training amongst the employees is responsible for poor training outcomes, especially in the civil service where incentives are low for personal development. The purpose of the study is to examine the relationships between peer support, superior support, training self-efficacy, training needs and opportunity to use on readiness to participate in training. The above goal would be achieved by determining the following objectives.

RO1: To determine the contributing factors to readiness to participate in training among civil Servants in Nigeria.

RO2: To determine the mediating role of opportunity to use on readiness to participate in Training among civil servants in Nigeria.

\section{Literature Reviews and Hypotheses Development Peer Support}

Peer support has become an important component of social support, especially on relevant organisational intervention such as training participation (Kukenberger, Mathieu \& Ruddy, 2015; Lleo, Viles, Jurburg \& Lomas, 2017). The support from referent group is crucial in building a result oriented organisational intervention such as readiness to participate in training. Group norm which is either implicit or explicit standards defined the pattern of behaviour among the group members (Hamilton \& White, 2008). The influence and support of peers can be viewed through the lens of social identity (White, Hogg \& Terry, 2002), where the prevailing group norms would most likely influence the individual behavioural disposition. From the perspective of social learning theory. Interactions, Interdependence and cooperation among employees stimulate readiness to participate on range of work-related activities such as sponsored training programme (Robinson, 2014), collaborative learning (Kukenberger et al, 2015; Schunn, Godley \& Demantino, 2016; Zou et al, 2019). Civil service, as a close knitted group embodies the influence of peers primarily on training participation, motivation to learn and effective transfer of leaned skills into the workplace (Adam-Manning, Pascale, Ohlson \& Croft, 2020; Nickerson, Cook \& Cruz, 2019; Rogers \& Ashforth, 2017). Chiaburu and Marinova (2005); Chiaburu and Tekleab (2005) discovered that, peer support was positively related with pre-training motivation. Pre-training motivation is suggestive of high readiness to participate in training. From the foregoing supporting evidence on the effect of peer support, these hypotheses are formulated in the context of the study.

H1a: Peer support has significant effect on opportunity to use training knowledge among civil servants in Nigeria.

H1b: Peer support has significant effect on readiness to participate in training 
program among civil servants in Nigeria.

\section{Superior Support}

Superior or Supervisor support is the second leg of social support which is equally crucial in managing training participation. The core issue which has not been properly established is that, some of the previous studies emphasised the importance of supervisor support on training transfer without understanding the status of employee readiness to participate in the training in the first instance (Bhatti et al, 2014; Kim et al, 2019; Park et al, 2018). This may be one of the reasons why training investments have failed to achieve the desired objectives in many organisations and sectors. Bhatti et al (2013) posited that superior support for training should be categorised in terms of time of training and type of support. The authors found a significant effect of superior support on motivation to transfer after training. Kim et al (2019) found that superior support mediated the effect of organizational support on readiness to participate, motivation to learn and training transfer. Superior support positively and significantly influences readiness to participate in training. Park et al (2018) found that supervisor support significantly affected motivation to learn.

$\mathrm{H} 2 \mathrm{a}$ : Superior support has significant effect on opportunity to apply training knowledge among civil servants in Nigeria.

$\mathrm{H} 2 \mathrm{~b}$ : Superior support has significant effect on readiness to participate in training program among civil servants in Nigeria.

\section{Training Self-Efficacy}

From the perspective of social cognitive theory, perceived self-efficacy is the individual ability to engage in a particular task and his/her persistency to complete the task in other to achieve a desired goal or outcome (Bandura, 1977; 1986; 2015). In the current study, training selfefficacy is the individual civil servant belief on his/her ability to attend and successfully complete a given training program. Self-efficacy is also context and task dependent (Olivier, Archambaut, Clercq \& Galand, 2019; Quintero, 2020). Context driven, self-efficacy measures self-efficacy in terms of organizational domain, sector or industry which requires specific characteristics which is consistent with the particular domain or context (Yokoyama, 2019; Zimmerman \& Kulikowich, 2016). Task driven self-efficacy focuses on the particular task which presumed self-efficacy will achieve (Nardi \& Ranieri, 2019; Yildiz-Durak, 2018). From the foregoing perspective, it is important to note that training self-efficacy and its role on training participation is critical in civil service where promotion and rewards are based on tenure and loyalty instead on performance and competency (Mohammad \& Osman, 2017; Olaopa, 2018). Previous studies have examined self-efficacy in context-specific situations in other to understand the connection between individual self-efficacy and range of behavioural dispositions towards the concept or issue. For example, Nardi and Ranieri (2019) and YildizDurak (2018) examined technology self-efficacy and computer related self-efficacy. Chen (2014); Tiapiutorus, Hansen \& Brown (2012a), Zimmerman and Kulikowich, (2016), focused on, online self-efficacy and web-based learning self-efficacy. In most of the above studies, the main conclusion was that, an individual with strong self-efficacy would most likely show strong disposition towards relevant technology and internet related training programs. Other scholars have found that individual with strong efficacy would be more likely to persist in a challenging task in other to achieve the desired goal (Kilicer, Badakci \& Arpaci, 2018) and improved coping disposition, which is closely associated with high readiness to learn (Bandura, 1997; Sadi \& Uyar, 2013) and autonomy and confidence to participate in training 
programs (Bai, 2017; Shen, Cho \& Tsai, 2013). Even though, most of the previous studies, argued that, an individual with strong self-efficacy would most likely have strong inclination to participate in training together with ability to cope with difficult and challenging task. This generalist view may not always hold without a conducive and enabling environment to use or apply the knowledge gained from training (Gegenfurtner et al, 2009b; Tracey \& Tews, 2005).

H3a: Training self-efficacy has significant effect on opportunity to apply training knowledge among civil servants in Nigeria.

H3b: Training self-efficacy has significant effect on readiness to participate in training program among civil servants in Nigeria.

\section{Training Needs}

Proper training needs analysis according to Gegenfurtner et al, (2009a) involves three key decisions:(1) status of the training program (mandatory or voluntary) (2) comprehensive information on the training prior to the training program and (3) quality feedbacks and constructive inputs from the trainees. Salas, Tannenbaum, Kraiger \& Smith-Jentsch (2012) argued that effective training need analysis should focus on (1) organisation need analysis, which examines the segment of the organisation where training is needed (2) task analysis, which addresses the specific task which the proposed training will achieve and (3) the individual analysis, which focuses on the employees that required the training. If these key decisions are effectively examined prior to the training program, it is believed that employee's readiness to participate would be high together with strong motivation to transfer (Ismail, Mohamed, Suliaman, Sabhi, 2010; Noe, Clarke \& Klien, 2014). Although, substantial studies have examined the link between training needs and range of training outcomes such as motivation to transfer (Bell, Tannenbaum, Ford \& Noe, 2017; Massenberg et al., 2015), the link between training needs, opportunity to use and readiness to participate has not been fully examined in the civil service from developing countries perspective. Sub-optimal performance in many government organisations, especially from developing countries is suggestive that training needs should be critically examined in the context of opportunity to use (apply) and resultant readiness to participate. From the perspective of training needs, the following hypotheses are formulated.

$\mathrm{H} 4 \mathrm{a}$ : Training needs has significant effect on opportunity to apply training knowledge among civil servants in Nigeria.

$\mathrm{H} 4 \mathrm{~b}$ : Training needs has significant effect on readiness to participate in training program among civil servants in Nigeria.

\section{Opportunity to Use}

When employees are assured that there is an opportunity to practice what they learnt; readiness to participate in training would be strong and positive together with high propensity to transfer the knowledge and skills into the workplace (Noe et al, 2014; Salleh et al, 2017). Even though, this construct had been examined in some of the previous studies, most of the studies were done in the private sector mostly in Western and Asian countries (Lauzier \& Mercier, 2017; Ng, 2015; Zhou, Schunn, Wang \& Zhang, 2019; Zumrah, 2015), which may not fully represent the current realties in many emerging countries. Civil service in many developing countries like Nigeria is notoriously redundant and embarrassingly ineffective in terms of service delivery. The opportunity to use training knowledge by the employees would lead to strong readiness to participate in training. Even though, peer support, superior 
support, training self-efficacy and training needs are closely related with readiness to participate; without conducive and enabling opportunity to apply the training knowledge, strong readiness to participate would be difficult. From the perspective of opportunity to use, the following hypotheses are formulated.

H5a: Opportunity to use mediates the effect of peer support on readiness to participate in training among civil servants in Nigeria.

H5b: Opportunity to use mediates the effect of superior support on readiness to participate in training among civil servants in Nigeria.

$\mathrm{H} 5 \mathrm{c}$ : Opportunity to use mediates the effect of training self-efficacy on readiness to participate

in training among civil servants in Nigeria.

$\mathrm{H} 5 \mathrm{~d}$ : Opportunity to use mediates the effect of training needs on readiness to participate in training among civil servants in Nigeria.

H6: Opportunity to use has significant effect on readiness to participate in training program among civil servants in Nigeria.

\section{Readiness to Participate in Training}

Employee readiness to participate is the willingness and preparedness of employees to attend and successfully complete a training program (Baharim, 2008). Noe et al (2014) argue that employee readiness is the belief that an employee has the ability, attitude and motivation to attend and successfully participate in training. The authors posit that, such features are necessary for the employee to learn the training program and apply the training contents successfully in the workplace. Following the extensive review of the relevant studies, five factors (peer support, superior support, training self-efficacy, training needs and opportunity to use) were identified as the plausible predictors of readiness to participate in training among civil servants in Nigeria. Accordingly, predictors of readiness to participate in training among civil servants is conceptually as represented in Figure 1.

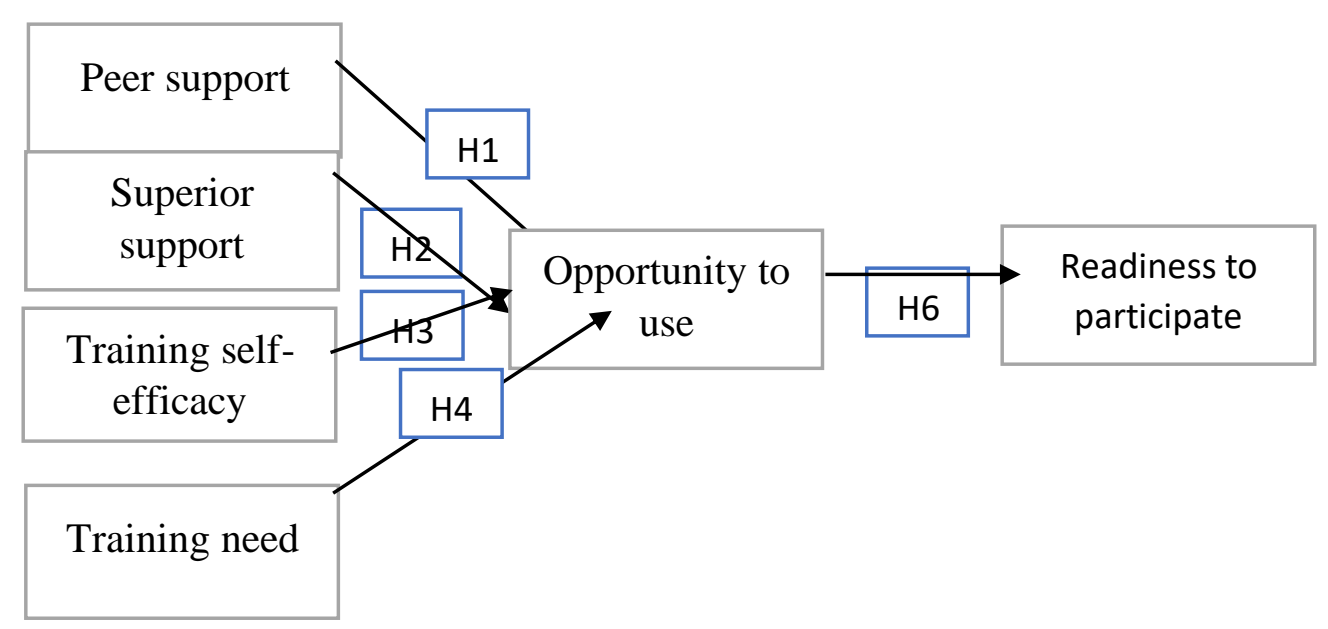

Figure 1: Research framework 


\section{Research Design and Methodology}

Following the literature reviews, five factors were identified as the most likely predictors of readiness to participate in training among civil servants (peer support, superior support, training self-efficacy, training needs and opportunity to use). Research design is the structured method of conducting a study in terms of data collection and analysis (Ary, Jacobs \& Sorensen, 2010; Kumar, 2011). Consistent with positivist research paradigm (hypotheticodeductive model) which is driven by explanation and prediction (Hair et al., 2010), the research design of the current study will be based on descriptive-survey method. The choice of descriptive-survey approach is due to the following reasons: (1) the method is mostly suitable to explain and predict the role of peer support, superior support, training selfefficacy, training needs and opportunity to use on readiness to participate in training (2) descriptive-survey is preferred when the researcher wants to study specific information of the population, in this case civil servants readiness to participate in training in Nigeria (3) selfreport method of data collection is mostly suitable for survey research (4) survey method is preferable when a sample of the population are selected to study and make generalization on the target population (5) finally, survey method is the preferred method to achieve the research objectives by explaining the contribution and role of each of factor in predicting readiness to participate in training among civil servants in Nigeria (Ary et al, 2010; Hair et al, 2010; Kumar et al, 2011; Saunders et al, 2009).

\section{Population and Sampling Method}

The study was conducted in three organisations in Abuja, the capital of Nigeria. It is important to note that approvals to carry out the study were received from the respective organisations. However, the three organisations requested that their names should not be mentioned in the study. The researcher in agreement with the principal officers of the three organisations agreed to adopt $(A, B, C)$ to represent the organisation. Sample of the study are career civil servants who have participated in training program in the last twelve months (JanuaryDecember, 2019). The one-year time frame is consistent with previous studies on training participation, especially on readiness and motivation to learn (Grohmann \& Kaufffeld, 2013). 500 copies of the questionnaires were distributed while 400 were retuned. However, only 255 were deemed valid for the final analysis (See table 1) for detailed information on questionaries distribution and collection. Proportional stratified sampling method was adopted in selecting the participants.

Table 1: Questionnaire Distribution and Collection

\begin{tabular}{clll}
\hline Organization & Quantity & Valid & Percentage \\
\hline A & 222 & 113 & $44.4 \%$ \\
B & 152 & 78 & $30.4 \%$ \\
C & 126 & 64 & $25.2 \%$ \\
Total & 500 & 255 & $100 \%$ \\
\hline
\end{tabular}

\section{Measurement}

The questionnaire was divided into two parts; part one covered the demographic information which contains (gender, age group, educational level, grade level and years of service). Part two assessed each of the six constructs of the study ( $A, B, C, D, E$ and F), for peer support, superior support, training self-efficacy, training needs, opportunity to use and readiness to 
participate respectively. The researcher used 31 items ( 27 adopted) from previously validated instruments and 4 self-developed. Each of the construct of the study was measured on a fivepoint Likert scale of increasing-increasing order (1) strongly disagree (2) disagree (3) neutral (4) agree (5) strongly agree. Peer support was measured with six items, which included 4 items adopted from Learners transfer system inventory by Holt, Bates, Seyler \& Carvalho (1997) and two self-developed items. Sample item includes: "At work, my colleagues expect me to use what I learn in training." In the civil service, peer support is primarily vital in promoting readiness to participate in training due to expected application of the learned skills in the workplace. Superior support was measured with seven items which included six items, adopted from Holt et al (1997) and one self-developed. Sample item includes: "My superior shows interest in what I learn in training." The quality of superior support in terms of interest, feedbacks and encouragements are vital in the civil service especially from developing country perspective where loyalty and tenure determine major decisions.

Training self-efficacy was measured with five items, which were adopted from Machin and Fogarty (1997). Sample item includes: "I am confident in my ability to perform satisfactorily on the training program." Training need was assessed with six items adopted from Noe and Wilk (1993). Sample item includes: "In this organization, I have freedom to choose the training program I want to attend." Opportunity to use was measured with four items adopted from Holt et al (1997). Sample item includes: "The resources I need to use what I learned will be available to me after training." Finally, readiness to participate was measured with six items. Five of the items were adopted from Holt et al (1997) while one item was self-developed. Sample item includes: "Training will increase my personal performance". Pilot study was conducted after instrument validation by four independent experts on human resource development, from faculty of educational studies, Universiti Putra Malaysia. Forty sample were used in the pilot study ( 20 from organisation $A$, and 10 each from B and C). The insights from the pilot study and experts' comments were vital in rewording some of the items to covey the intended information of each construct. 
Table 2: Demographic Information ( $N=255)$

\begin{tabular}{lll}
\hline Characteristics & Frequency & (\%) \\
Gender & 106 & 41.6 \\
Male & 149 & 58.4 \\
Female & & \\
Age group & 17 & 6.7 \\
$20-26$ & 54 & 21.2 \\
$27-33$ & 53 & 20.8 \\
$34-40$ & 47 & 18.4 \\
$41-47$ & 44 & 17.3 \\
$48-54$ & 40 & 15.7 \\
$\geq 55$ & & \\
Education & 60 & 23.5 \\
Scholl cert/Diploma & 84 & 32.9 \\
Bachelor & 73 & 28.6 \\
Masters & 26 & 10.2 \\
PhD & 12 & 4.7 \\
Professional qualification & & \\
Grade level & & 18.0 \\
$1-6$ & 46 & 62.4 \\
$7-10$ & 159 & 19.6 \\
$12-14$ & 50 & \\
Number of years in service & & 10.6 \\
$1-5$ & 27 & 31.8 \\
6-10 & 81 & 8.2 \\
$11-15$ & 21 & 23.9 \\
$16-20$ & 61 & 4.7 \\
$21-25$ & 53 & \\
$\geq 26$ & 12 & \\
\hline
\end{tabular}

Note: ${ }^{\text {a: }}$ There is no grade level 11 in Nigeria civil service system. The highest-grade level is 17 which is the position for permanent secretary. It should be noted that, GL 17 does not confer

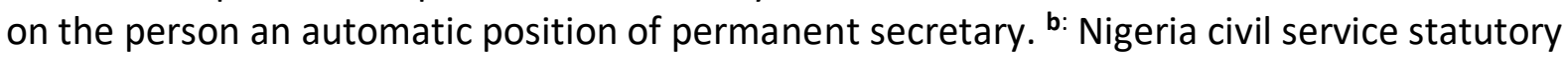
retirement is 35 years of active service or 60 years of age (whichever comes first).

\section{Statistical Method}

Structural equation modelling is the preferred statistical method used to analyse the collected data. The choice of SEM is predicated on two key advantages: firstly, it helps the researcher to examine multiple structural relationships. Secondary, it assists in specifying concepts and theories of the study (Byrne, 2010; Wang \& Wang, 2012). In the current study, exploratory factor analysis and confirmatory factor analysis were examined in other to establish the suitability and validity of the scale of the measurement. Two step measure were adopted (1) measurement model and (2) structural model (Hair, Black \& Babin, 2010). It is on the validity of the measurement model that the structural part would be examined for hypothesis testing. Convergent validity was evaluated with average variance extracted (AVE) while discriminant validity was assessed with the square root of AVE, which should be greater than inter construct correlation. Although it is recommended that at least an index should be chosen 
from each of the three classifications (absolute fit indices, incremental fit indices and parsimonious fit indices), RMSEA, GFI, CFI and Chisq/df were the most widely used fitness index (Awang, Afthanorhan \& Mamat, 2015). Even though, there is no unanimously accepted threshold for fit indices, statistical experts have suggested some rule to be followed when accepting fit indices. Hair et al (2010) posit that, if the sample size is between 250 and 1000, $\mathrm{CFI}$ ought to be greater than 0.90 . Also, a sample size of more than 250 together with CFI of greater than 0.90 should have a RMSEA of less than 0.80 . Schumacher and Lomax (2010) argue that GFI should be at least 0.80 and Chisq/df should be less than 5 .

\section{Reliability and Validity}

\section{Table 3: Convergent validity}

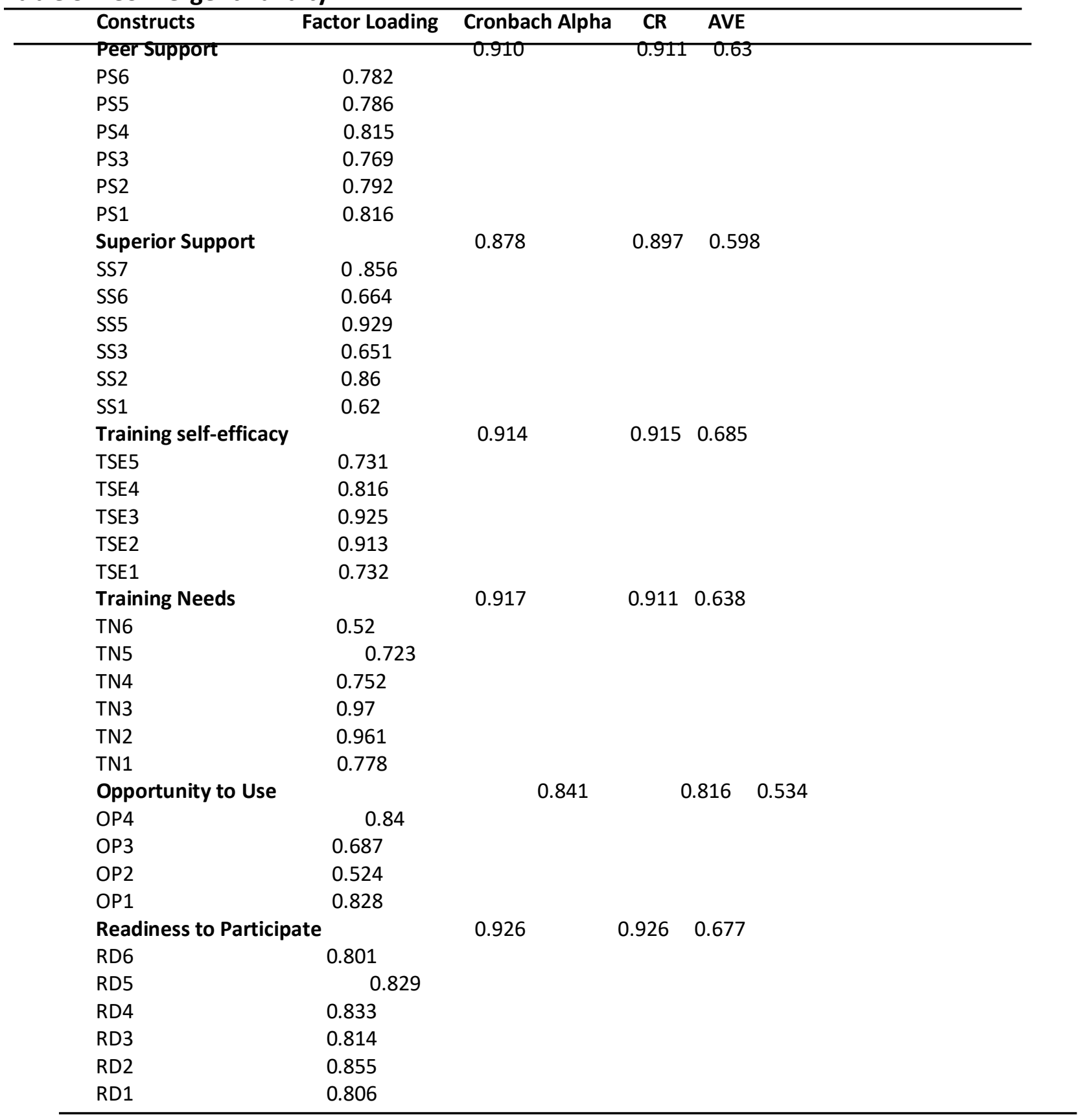

Table 3 showed the reliability and validity estimates. Specifically, the Cronbach alpha ranges from 0.841 for opportunity to use to 0.926 for readiness to participate respectively, which is 
greater than 0.7 threshold. Composite reliability (CR) for the latent variables ranges from 0.816 to 0.926 , which is greater than 0.7 recommended threshold (Hair et al, 2010). Convergent validity was assessed with average variance extracted (AVE), which ranges from 0.534 for opportunity to use to 0.685 for training self-efficacy, which is higher than 0.5 recommended threshold. From the information, the dataset enjoys improved reliability and acceptable convergent validity. The indicator SS4 was removed due to poor factor loading.

Table 4: Discriminant validity

\begin{tabular}{llllllll}
\hline & PS & SS & TSE & TN & OP & RD \\
\hline PS & $\mathbf{0 . 7 9 4}$ & & & & & & \\
SS & 0.212 & $\mathbf{0 . 7 7 3}$ & & & & \\
TSE & 0.358 & 0.374 & $\mathbf{0 . 8 2 8}$ & & & \\
TN & 0.181 & 0.34 & 0.323 & $\mathbf{0 . 7 9 9}$ & & \\
OP & 0.351 & 0.506 & 0.454 & 0.419 & $\mathbf{0 . 7 3 1}$ & \\
RD & 0.495 & 0.446 & 0.448 & 0.332 & 0.711 & $\mathbf{0 . 8 2}$ \\
\hline
\end{tabular}

Table 4 showed the discriminant validity estimate. By convention, the square root of AVE of each construct should be greater than inter-construct correlation (Hair et al, 2010). This threshold was met because the square root of AVE of each construct as shown on top each of construct is greater than inter-construct correlations; hence discriminant validity criterion was achieved.

\section{Measurement Model Assessment}

On completion of the CFA, the next step in SEM is to examine the measurement model by fitting the individual constructs and assessing its measurement validity, otherwise the measurement model will be modified (Awang et al, 2015). In the current study, the initial measurement model was not valid because of poor RMSEA of 0.106 , which was modified. All the fit indices were met; Chi-square/df: 1.314, GFI: 0.871, CFI: 0.976, IFI: 0.976, RMSEA: 0.35.

\section{Structral Model Assessment}

The second component of SEM is the evaluation of the structural validity. Structural part specify the relationships betweeen independent (exogenous) and depedent (endogenous) variables (Hair et al, 2010). Unlike the measurement model which connect measured variables to latent variables, structural model connects latent variables to one another (Byrne, 2010). In the current study, the structural model was assessed to show the predictive validity of (peer support, superior support, training self efficacy, training needs and opportunity to use) on readiness to participate in training among civil servants in Nigeria. As indicated on figure 2, all the fitness parameters were met (Chi-square/df: 1.314, GFI: 0.871, CFI: 0.976, IFI: 0.976, RMSEA: 0.35). The model is suitable to test the accompanying hypotheses. 


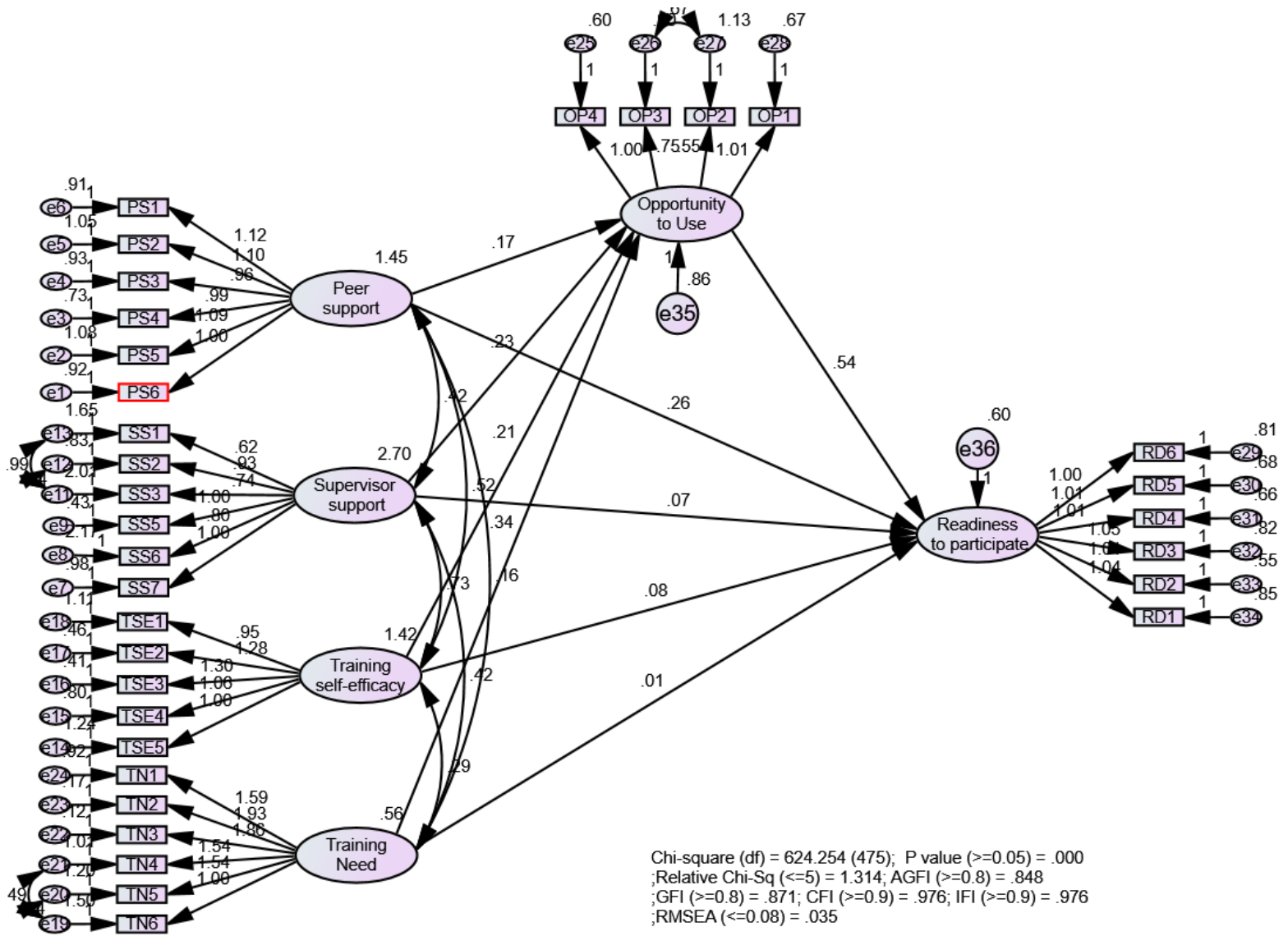

Figure 2: Structural model

Results and hypotheses testing

Table 5: Direct relationship results

\begin{tabular}{|l|l|l|l|l|l|l|l|}
\hline Hypo & Path & $\boldsymbol{\beta}$ & BETA & S.E. & C.R. & P & Result \\
\hline H1a & OP <--- PS & 0.17 & 0.171 & 0.064 & 2.648 & 0.008 & Supported \\
\hline H1b & RD <--- PS & 0.259 & 0.259 & 0.057 & 4.512 & $* * *$ & Supported \\
\hline H2a & OP <--- SS & 0.235 & 0.321 & 0.049 & 4.759 & $* * *$ & Supported \\
\hline H2b & RD <--- SS & 0.065 & 0.089 & 0.044 & 1.478 & 0.139 & Not supported \\
\hline H3a & OP <--- TSE & 0.205 & 0.204 & 0.07 & 2.942 & 0.003 & Supported \\
\hline H3b & RD <--- TSE & 0.077 & 0.076 & 0.06 & 1.296 & 0.195 & Not supported \\
\hline H4a & OP <--- TN & 0.343 & 0.213 & 0.107 & 3.197 & 0.001 & Supported \\
\hline H4b & RD <--- TN & 0.007 & 0.004 & 0.088 & 0.08 & 0.936 & Not supported \\
\hline H6 & RD <--- OP & 0.543 & 0.539 & 0.079 & 6.879 & $* * *$ & Supported \\
\hline
\end{tabular}


Table 6: Direct, indirect and total effects

\begin{tabular}{|l|l|l|l|l|l|}
\hline Hypothesis & Construct & Direct & Indirect & Total & Results \\
\hline H5a & PS & $0.259(0.002)$ & $0.092(0.004)$ & $0.351(0.002)$ & Partial mediation \\
\hline H5b & SS & $0.089(0.141)$ & $0.173(0.002)$ & $0.262(0.002)$ & Full mediation \\
\hline H5c & TSE & $0.076(0.181)$ & $0.11(0.008)$ & $0.186(0.006)$ & Full mediation \\
\hline H5d & TN & $0.004(0.949)$ & $0.115(0.004)$ & $0.119(0.046)$ & Full mediation \\
\hline
\end{tabular}

\section{Discussion and Implications}

Hypothesis testing is the last segment of the data analysis where the significance of the path coefficients are exmained. For the direct relationships, six hypotheses were supported $(\mathrm{H} 1 \mathrm{a}$, $\mathrm{H} 1 \mathrm{~b}, \mathrm{H} 2 \mathrm{a}, \mathrm{H} 3 \mathrm{a}, \mathrm{H} 4 \mathrm{a}$ and $\mathrm{H6}$ ). Also, three hypotheses were not suported ( $\mathrm{H} 2 \mathrm{~b}, \mathrm{H} 3 \mathrm{~b}$ and $\mathrm{H} 4 \mathrm{~b}$ ). Opportunity to use explained $40.5 \%$ of the varaince in the model while readiness to participate accounted for $58.6 \%$ of the variance. The purpose of the study is to examine the relationships between peer support, superior support, training self-efficacy, training needs and opportunity to use on readiness to participate in training, with a focus on the contributing factors to readiness to participate and the mediation role of opportunity to use on the readiness to participate. From the results of the study, the following critical insights and potential implications were examined: Civil service is a close braided group of employees all over the world where peer support is vital for individual and group participation on range of relevant interventions. From the results, it was found that only peer support and opportunity to use had direct significant relationships with readiness to participate. The implication is two folds, as a close knitted group with interaction and interdependency, the support from peers will have significant effect on readiness to participate. As a group, civil servants would have strong readiness to participate if there are opportunities to use the knowledge and skills acquired from training program. The current result is consistent with the studies by Aziz and Khatony (2019), Parikh-Foxx, Martinez, Baker \& Olsen (2020), Salleh et al (2017) on the predictors of readiness to participate.

The fully mediated effect of opportunity tom use, on superior support, training self-efficacy and training needs on readiness to participate is suggestive that, without opportunity to use the knowledge and skills acquired in the workplace; the effect of superior support, training self-efficacy and training needs would be less visible in the civil service. Furthermore, the partial mediation effect of peer support on readiness to participate is indicative that when opportunity to use is controlled, peer support would still exert significant effect on readiness to participate. Previous studies argue that individual self-efficacy is closely associated with strong behavioural disposition towards a concept or phenomenon (Bandura, 2015). The result of the study is indicative that, training self-efficacy without opportunity to use would not generate the needed improvement on readiness to participate in training especially in an agency where incentive for personal development is low. This particular finding is consistent with the result of Simosi (2012); Khalid (2020), that in an achievement driven organisation, employees are personally motivated to improve themselves unlike the civil service where loyalty and tenure determine everything.

\section{Conclusion}

Organizations spent huge sums of money and applicable resources on employee training in other to be competitive. Many training interventions have failed to achieve the desired outcomes due to poor readiness to participate among the employees. In the civil service where loyalty and tenure determine major policy interventions, employee's readiness to 
participate in training becomes challenging. In some of the previous studies on training related studies, efforts were focused on training transfer and applicable factors in other to achieve effective training outcomes. Although, this writer agreed in most of the propositions on training transfer. It is the considered view of this writer that employees should be ready and willing to participate in training before training intervention is introduced. Finally, civil service being an important agency of any government depends on the support and influence of superiors to implement relevant training programs. The current findings re-enforced the centrality of individual behavioural disposition as largely context dependent and situation specific. In private sector, employees are personally motivated to develop themselves due to potential career and job prospects. However, in the civil service especially in many developing countries the phrase "wait for your own turn" is being used to stifle innovation, learning and new ideas which makes the need for ascertaining staff readiness to participate in training, a policy priority. Civil servants are expected to deliver on numerous current and emerging priorities in an environment where learning will be transformed. The results of the current study have shown that, proper integration of individual and organizational factors is necessary to enthrone strong readiness to participate among civil servants with the resultant effect on service delivery, innovation, national productivity and sustained competitiveness.

\section{Limitations and Recommendations}

Although, the study provided a new information on readiness to participate in the civil service, there are noticeable limitations that require additional investigation. First, the study used self-report method of data collection which is susceptible to common method bias. Second, the study focused on five individual and organizational factors which influence readiness to participate. There are other factors which could affect employee readiness to participate. Third, the findings may not be widely generalised due to limitation imposed by contextual characteristics such as country, sector and sample. For example, civil servants globally share similar characteristics especially on the work they do. However, a country specific geography, culture, rules and level of development could affect wider application of the current findings in those locations, industries and settings. Also, in the private sector, employees may have different behavioural dispositions towards training due to incentives for personal, job and career prospects. Future studies could focus on other factors such as rewards, intention and perceived organisational support as an independent variable. Scholars may also explore the role of gender and other demographic characteristics in other to determine their influence on individual readiness to participate both in private and public sector. It is the submission of this researcher that, the findings from the study would stimulate improved scholarly attention towards human resource development in the new normal, where learning and knowledge acquisition would be transformed.

\section{References}

Adams-Manning, A., Pascale, A. B., Ohlson, M., \& Croft, L. S. (2020). Individual and Organizational Culture Predictors of Voluntary Participation in Training and Development Activities Among Student Affairs Professionals. College Student Affairs Journal, 38(1), 65-77.

Ary, D., Jacobs, L. C., \& Sorensen, C. K. (2010). Introduction to research in education (8th ed.). Belmont: Wadswort. 
Awang, Z., Afthanorhan, A., \& Mamat, M. (2015). The likert scale analysis using parametric based Structural Equation Modeling (SEM). Computational Methods in Social Sciences, $4(1), 13-21$.

Azizi, S. M., \& Khatony, A. (2019). Investigating factors affecting on medical sciences students' intention to adopt mobile learning. BMC Medical Education, 19(381), 1-10.

Baharim, S. B. (2008). The influence of knowledge sharing on motivation to transfer training: A Malaysian public sector context,. Victoria: University, Melbourne.

Bai, X. (2017). Promote technology self-efficacy via a SCORM-based e-learning approach. International Journal of Information and Education Technology, 7(8), 575- 580.

Bandura, A. (1977). Social learning theory. Englewood Cliffs: Prentice Hall.

Bandura, A. (1986). Social foundations of thought and action: A social cognitive theory. Englewood: Prentice Hall.

Bandura, A. (2015). On deconstructing commentaries regarding alternative theories of selfregulation. Journal of Management, 41(4), 1025-1044.

Banerjee, P., Gupta, R., \& Bates, R. (2016). Influenceoforganizational learning culture on knowledge worker's motivation to transfer training: testing moderating effects of learning transfer climate. Current Psychology, 36, 606-617.

Bates, R., Kauffeld, S., \& Holton, E. F. (2007). Examining the factor structure and predictive ability of the German-version of the learning transfer systems inventory. Journal of European Industrial Training, 31(3), 195-211.

Bell, B. S., Tannenbaum, S. I., Ford, J. K., Noe, R. A., \& . (2017). 100 years of training and development research: what we know and where we should go. The Journal of Applied Psychology, 102(3), 305-323.

Berkley, R. A., \& Kaplan, D. M. (2019). Strategic training and development. New York: SAGE Publications.

Bhatti, M. A., Ali, S., Isa, M. F., \& Battour, M. M. (2014). Training Transfer and Transfer Motivation: The Infl uence of Individual, Environmental Situational Training Design, and Aff ective Reaction Factors. Performance Improvement Quraterly, 1-33.

Bhatti, M. A., Battour, M. M., Sundram, V. P., \& Othman, A. A. (2013). Transfer of training: does it truly An examination of support, instrumentality, retention and learner readiness on the transfer motivation and transfer of training. European Journal of Training and Development , 37(3), 273-297.

Byrne, B. M. (2010). Structural equation modeling with AMOS: Basic concepts applications, and programming (2nd ed.). New York: Routledge.

Celestin, B. N., \& Yunfei, S. (2018). The impact of learner characteristics on training transfer expectation: a survey of Thai teachers' perception of cloud computing tools. International Journal of Training and Development, 22(4), 256-273.

Chen, Y. L. (2014). A study on student self-efficacy and technology acceptance model within an online task-based learning environment. Journal of Computers, 9(1), 34-43.

Chiaburu, D. S., \& Marinova, S. V. (2005). What predicts skill transfer? An exploratory study of goal orientation, training self-efficacy and organization supports. International Journal of Training and Development, 9, 110-123.

Chiaburu, D. S., \& Tekleab, A. G. (2005). Individual and contextual influence on multiple dimensions of training effectiveness. Journal of European Industrial Training, 29(8), 604-624. 
Chiaburu, D. S., Dam, K. V., \& Hutchins, H. M. (2010). Social Support in the Workplace and Training Transfer: A longitudinal analysis. International Journal of Selection and Assessment, 18(2), 1-15.

Ferreira, R. R., Abbad, G. S., \& Mourao, L. (2015). Training needs analysis at work. In K. Kraiger, J. Passmore, N. R. Santos, \& S. Malvezzi (Eds.), Handbook of the Psychology of Training Development, and Performance Improvement (pp. 32-49). Hoboken, New Jersey: Wiley, Blackwell.

Gegenfurtner, A. (2018). Testing the gender similarities hypothesis: differences in subjective task value and motivation to transfer training. Human Resource Development International, 1-13. Retrieved from https://doi.org/10.1080/13678868.2018.1449547

Gegenfurtner, A., Festner, D., Gallenberger, W., Lehtinen, E., \& Gruber, H. (2009b). Predicting autonomous and controlled motivation to transfer training. International Journal of Training and Development, 13(2), 124-138.

Gegenfurtner, A., Veermans, K., Festner, D., \& Gruber, H. (2009a). Motivation to transfer training: an integrative literature review. Human Resource Development Review, 8(3), 403-423.

Grohmann, A., \& Kaufffeld, S. (2013). Evaluating training programs Development and correlates of the questionnaire for professional training evaluation. International Journal of Training and Development, 17(2).

Grossman, R., \& Salas, E. (2011). The transfer of training: What really matters. International Journal of Training and Development, 15(2), 103-120.

Hair, J. F., Black, W. C., Babin, B. J., \& Anderson, R. E. (2010). Multivariate data Analysis . New Jersey: Prentice-Hall.

Hamilton, K., \& White, K. M. (2008). Extending the Theory of Planned Behavior: The Role of Self and Social Influences in Predicting Adolescent Regular Moderate-to-Vigorous Physical Activity. Journal of Sport \& Exercise Psychology, 30, 56-74.

Holton, E. F., Bates, R., Seyler, D. L., \& Carvalho, M. B. (1997). Towards Construct Validation of a Transfer Climate Instrument. Human Resources Development Quarterly, 8(2), 95113.

Holton, E. F. (2005). Holton's evaluation model: new evidence and construct elaborations. Advances in Developing Human Resources, 7, 37-54.

Holton, E. F., Bates, R., \& Kauffeld, S. (2007). "Examining the factor structure and predictive ability of the German-version of the learning transfer system inventory. Journal of European Industrial Training, 31(3), 195-211.

Hung, M. L. (2016). Teacher readiness for online learning: scale development and teacher perceptions. Computers\& Education, 94, 120-133.

Ismail, A., Mohamed, H. A., Suliaman, A. Z., \& Sabhi, S. (2010). Supervisor's Role as an Antecedent of Training Transfer. Acta Universitatis Danubius, 18-38.

Ivancevich, J. M., \& Lee, S. H. (2002). Human resource management in Asia. New York: McGraw-Hill.

Jones, R. A., Jimmieson, N. R., \& Griffiths, A. (2005). The Impact of Organizational Culture and Reshaping Capabilities on Change ImplementationSuccess: The Mediating Role of Readiness for change. Journal of Management Studies 42,, 361-386.

Kilicer, K., Bardakci, S., \& Arpacı, I. (2018). Investigation of emerging technology usage characteristics as predictors of innovativeness. Contemporary Educational Technology, 9(3), 225-245. 
Kim, E. J., Park, S., \& Kang, H. S. (2019). Support, training readiness and learning motivation in determining intention to transfer. European Journal of Training and Development, 44(3/4), 3016-321.

Khalid, N. (2020). Artificial intelligence learning and entrepreneurial performance among university students: evidence from malaysian higher educational institutions. Journal of Intelligent \& Fuzzy Systems, (Preprint), 1-19.

Kukenberger, M. R., Mathieu, J. E., \& Ruddy, T. (2015). A Cross-Level Test of Empowerment and Process Influences on Members' Informal Learning and Team Commitment. 41(3), 987-1016.

Kumar, C. R. (2011). Research methodology: A step by step guide for beginners. London: Sage Publications.

Lauzier, M., \& Mercier, G. (2018). The effect of error orientation, motivation to learn, and social. Canadian Journal of Administrative Sciences, Advance online publication, 35(2), 419-428.

Liebermann, S., \& Hoffmann, S. (2008). The impact of practical relevance on training transfer:evidence from a service quality training program for German bank clerks. International Journal of Training and Development, 12(2), 74-86.

Machin, M. A., \& Treloar, C. A. (2004). Predictors of motivation to learn when training is mandatory. Retrieved July 7, 2020, from

228515987_Predictors_of_motivation_to_learn_when_training_is_mandatory

Mafini, C., \& Dlodlo, N. (2014). The Relationship between Extrinsinc Morivation, Jon Satisfaction and life Satisfaction among employees in public organisation. South Africa Journal of Industrial Psychology, 40, 1-12.

Massenberg, A. C., Spurk, D., \& Kauffeld, S. (2015). Social support at the workplace, motivation to transfer and training transfer: a multilevel indirect effects model. International Journal of Training and Development, 19(3), 161-178.

Mohamad, N., \& Osman, K. (2017). Self-efficacy as mediator between learning and behaviour among in-service science teachers training programme of higher order thinking skills. The Eurasia Proceedings of Educational \& Social Sciences, 6, 177-188.

Nardi, A., \& Ranieri, M. (2019). Comparing paper-based and electronic multiple-choice examinations with personal devices: impact on students' performance, self-efficacy and satisfaction. British Journal of Educational Technology, 50(3), 1495-1506.

Nawab, S., \& Bhatti, K. K. (2015). The Infleunce of Employee Compensation of Organizational Commitment and Job Satisfaction: A case study of Educational Sector of Pakistan. International Journal of , 2, 25-32.

Ng, K. H. (2015). "Supervisory practices and training transfer: lessons from Malaysia. Asia Pacific Journal of Human Resources, 53(2), 221-240.

Nickerson, A. B., Cook, E. A., \& Cruz, M. A. (2019). Transfer of School Crisis Prevention and Intervention Training Knowledge, and Skills: Training, Trainee, and Work Environment Predictors. School Psychology Review, 48(3), 237-250.

Nijman, D. M., Nijhof, W. J., Wognum, A. M., \& Veldkamp, B. P. (2006). Exploring differential eff ects of supervisor support on transfer of training. Journal of European Industrial Training, 30(7), 529-549.

Noe, R. A., \& Colquitt, J. A. (2002). Planning for training impact: Principles of effectiveness. In $K$. Kraiger (Ed.), Creating, implementing, and managing effective training and development. San Fransisco: Jossey-Bass. 
Noe, R. A., \& Wilk, S. L. (1993). Investigation of the factors that influence employees' participation in development activities. Journal of Applied Psychology, 78(2), 291-302.

Noe, R. A., Clarke, A. M., \& Klein, H. J. (2014). Learning in the Twenty-FirstCentury Workplace. The Annual Review of Organizational Psychology, 247-275.

Noe, R. A., Twes, M. J., \& Marand, S. D. (2013). Individual differences and informal learning in the workplace. Journal of Vocational Behavior, 83, 327-335.

Olaopa, T. (2018). 1974: How reformed is the Civil Service? Retrieved November 26, 2020, from http://thenationonlineng.net/1974-how-reformed-is-thecivil-service/

Olivier, E., Archambault, I., De Clercq, M., \& Galand, B. (2019). Student self-efficacy, classroom engagement, and academic achievement: comparing three theoretical frameworks. Journal of Youth and Adolescence, 48(2), 326-340.

Parikh-Foxx, S., Martinez, R., Baker, S. B., \& Olsen, J. (2020). Self-Efficacy for Enhancing Students' Career and College Readiness A Survey of Professional School Counselors. Journal of Counseling \& Development, 98, 183-192.

Park, S., Kang, H. S., \& Kim, E. J. (2018). The role of supervisor support on employees' training and job performance: an empirical study. European Journal of Training and Development, 42(1/2), 57-74.

Payne, S. L., Flynn, J., \& Whitfield, J. M. (2008). Capstone business course assessment Exploring student readiness perspectives. Journal of Education for Business, 83(3), 141-146.

Quintero, J. M. (2020). I Think I Can; I Know I Can: Self-Efficacy as an Indicator of Learner SelfSatisfaction with the Learning Experience in an Online Master of Social Work Program. PhD dissertation, Texas State University, San Marcos.

Robinson, J. D. (2014). The Learning Coupon: The Effect of Peer and Supervisors Participation on Individual Participation in An Employer Sponsored Professional Development Initiative. University of Maryland, Graduate Studies. Maryland: University of Maryland. Retrieved September 1st, 2020, from file:///C:/Users/MY\%20HP/Desktop/Robinson.pdf

Rogers, K. M., \& Ashforth, B. (2017). Respect in Organizations: Feeling Valued as We" and "Me. Journal of Management, 43(5), 1578-1608.

Saad, A. M., Mat, N. B., \& Awadh, A. M. (2013). Review of theory of human resources development training (learning) participation. (pp. 85-92). Antalya: WEI International Academic Conference Proceedings.

Sadi, O., \& Uyar, M. (2013). The relationship between self-efficacy, self-regulated learning strategies and achievement: a path model. Journal of Baltic Science Education, 12(1), 21-33.

Salas, E., Tannenbaum, S. I., Kraiger, K., \& Smith-Jentsch, K. A. (2012). The science of training and development in organizations: what matters in practice. Psychological Science in the Public Interest, 13(2), 74-101.

Salleh, N. N., Amin, M. A., \& Mamat, I. (2017). Employee Readiness, Training Design and Work Environment in Influencing Training Transfer Among Academic Staffs of Uitm. International Journal of Academic Research in Business and Social Sciences, 7(10), 275290.

Saunders, M., Lewis, P., \& Thornhill, A. (2009). Research Methods for Business Students. Essex: FT Prentice Hall.

Schumacker, R. E., \& Lomax, R. G. (2010). A beginner's guide to structural equation modeling. (3rd ed.). New York: Routledge. 
Schunn, C., Godley, A., \& DeMartino, S. (2016). The Reliability and Validity of Peer Review of Writing in High School AP English Classes. Journal of Adolescent \& Adult Literacy, 1-11. Retrieved September 1st, 2020, from http://www.Irdc.pitt.edu/Schunn/papers/Schunn_et_al-2016-JAAL.pdf

Shen, D., Cho, M. H., Tsai, C. L., \& Marra, R. (2013). Unpacking online learning experiences: online learning self-efficacy learning satisfaction. Internet and Higher Education, 19, 10-17.

Simosi, M. (2012). The moderating role of self-efficacy in the organizational culture-training transfer relationship. International Journal of Training and Development, 16(2), 92106.

Taipjutorus, W., Hansen, S., \& Brown, M. (2012a). Investigating a relationship between learner control and self-efficacy in an online learning environment. Journal of Open and Flexible Distance Learning, 16(1), 56-69.

Tracey, J. B., \& Tews, M. J. (2005). Construct validity of a general training climate scale. Organizational Research Methods, 8, 353-74.

Training Industry Magazine. (2019). 2019 Training Industry Report. Retrieved November 23, 2020, from https://trainingmag.com/sites/default/files/2019_industry_report.pdf

Treuer, K., Karantzas, G., McCabe, M., Melor, D., Konis, A., Davison, T. E., \& O’Connor, D. (2018). Organizational factors associated with readiness for change in residential aged care settings. BMC Health Sciences Research, 18(77), 1-6.

Velada, R., \& Caetano, A. (2007). Training transfer: the mediating role of perception of learning',. Journal of European Industrial Training, 31, 283-296.

Vignoli, M., Mariani, M. G., Guglielmi, D., \& Violante, F. S. (2017). Leadership styles and selfefficacy in determining transfer intentions of safety training. 30(4). doi:10.1108/JWL01-2017-0001

Wang, X., \& Wang, J. (2012). Structural equation modeling: Applications using Mplus. West Sussex: Wiley.

White, K. M., Hogg, M. A., \& Terry, D. J. (2002). . Improving attitude-behavior correspondence through exposure to normative support from a salient ingroup. Basic and Applied Social Psychology, 24, 91-103.

Willyerd, K., \& Mistick, B. (2016). Stretch: How to Future-Proof Yourself for Tomorrow's Workplace (1st ed.). Hoboken: NJ: Wiley.

World Economic Forum. (2018). The Future of Jobs. Geneva: World Economic Forum.

Yildiz-Durak, H. (2018). Flipped learning readiness in teaching programming in middle schools:modelling its relation to various variables. Journal of Computer Assisted Learning, 34(6), 939-959.

Yokoyama, S. (2019). Academic self-efficacy and academic performance in online learning: a mini review. Retrieved November 26, 2020, from https://doi.org/10.3389/fpsyg.2018.02794

Zhou, L. L., Owusu-Marfo, J., Antwi, H. A., Antwi, M. O., Kachie, A. D., \& Ampon-Wireko, S. (2019). "Assessment of the social influence and facilitating conditions that support nurses'adoption of hospital electronic information management systems (HEIMS) in Ghana using the unified theory of acceptance and of technology (UTAUT). BMC Medical Informatics and Decision Making, 19(23), 1-19. 
Zimmerman, W., \& Kulikowich, J. (2016). Online learning self-efficacy in students with and without online learning experience. American Journal of Distance Education, 30(3), 180-191.

Zumrah, A. R. (2015). Examining the relationship between perceived organizational support, transfer. European Journal of Training and Development, 39(2), 143-160. 